\title{
Prion protein gene polymorphism in four West African sheep populations
}

\author{
Amadou Traoré • Luis J. Royo • Adama Kaboré • \\ Lucía Pérez-Pardal • Isabel Álvarez • Iván Fernández • \\ Laya Sawadogo • Hamidou H. Tamboura • \\ Félix Goyache
}

Accepted: 19 January 2012 / Published online: 31 January 2012

(C) Springer Science+Business Media B.V. 2012

\begin{abstract}
A total of 162 individuals, belonging to three Burkinabé and one Niger sheep populations, were analysed for prion protein $(\mathrm{PrP})$ gene polymorphism at codons 136 , 154 and 171. The ARQ allele was the most frequent in both the Burkinabé (86.7\%) and the Niger (67.5\%) sheep populations. The highly sensitive allele VRQ was not found in the sampled individuals. The highly resistant ARR allele was in very low frequency in the Burkina-Sahel (4.4\%) and Mossi (3.2\%) populations and was not present in the Djallonké and Touareg populations. Only 4 out of 15 possible PrP genotypes were identified in the sampled individuals. No favourable ARR/ARR genotypes were found in either of the breeds. Sequencing a subgroup of the samples allowed the identification of other five polymorphisms on the PrP gene sequence at codons 116, 138, 151, 237 and 240. The very low frequency of the ARR allele in the West African sheep should dissuade the implementation of a preventive selection programme aimed to increase resistance to scrapie, to avoid an extreme erosion of the genetic stock.
\end{abstract}

A. Traoré $\cdot$ A. Kaboré $\cdot$ H. H. Tamboura

INERA,

04 BP 8645, Ouagadougou 04, Burkina Faso

A. Traoré $(\triangle) \cdot$ L. J. Royo $\cdot$ L. Pérez-Pardal $\cdot$ I. Álvarez

I. Fernández $\cdot$ F. Goyache $(\bowtie)$

SERIDA-Deva,

Camino de Rioseco 1225,

33394 Deva-Gijón, Asturias, Spain

e-mail: traore_pa@yahoo.fr

e-mail: fgoyache@serida.org

L. Sawadogo

Université de Ouagadougou (UFR/SVT),

03 BP 7021, Ouagadougou 03, Burkina Faso
Keywords PrP · Scrapie $\cdot$ RT-PCR genotyping $\cdot$ Sahelian sheep · Dwarf sheep · West Africa

\section{Introduction}

Scrapie is one of the diseases of the group of transmissible spongiform encephalopathies, which include CreutzfeldtJakob disease in humans and bovine spongiform encephalopathy (BSE) in cattle. The variations at amino acid codons $136(\mathrm{~A} / \mathrm{V}), 154(\mathrm{R} / \mathrm{H})$ and $171(\mathrm{Q} / \mathrm{R} / \mathrm{H} / \mathrm{K})$ of the $\operatorname{PrP}$ gene have been shown to be particularly important in genetic susceptibility to classical scrapie (Heaton et al. 2003; Lühken et al. 2008). Polymorphisms at other codons are rare and have not yet been associated with classical scrapie susceptibility. Nowadays, there is an increasing interest to know PrP genotype and allelic frequencies in different sheep populations to carry out association studies with clinical scrapie (Ekateriniadou et al. 2007; Lühken et al. 2008), ascertain how selection for scrapie resistance can affect selective programmes for performance traits (Alfonso et al. 2006) or conservation programmes (Álvarez et al. 2007, 2009a; Windig et al. 2007), and document the variability of PrP gene in areas in which, to date, scrapie cases are few or have not been reported (Gootwine et al. 2008; Passos et al. 2008; Ün et al. 2008) to prepare for possible classical scrapie outbreaks (Kipanyula et al. 2009; Álvarez et al. 2011).

Although many studies have described the genetic susceptibility of scrapie in European sheep breeds, little is known about sheep populations with other origins. Reports on PrP polymorphism in African sheep are scant (Serrano et al. 2007; Kipanyula et al. 2008, 2009). There is an increasing interest in the assessment of African sheep diversity (Nsoso et al. 2004; Almeida 2011). The aim of this research is to ascertain the genotypic and allelic frequencies of $\operatorname{PrP}$ 
gene in three Burkina Faso and one Niger sheep populations (Traoré et al. 2008a) to increase the information on this issue in Africa and gain understanding on the genetic diversity in West African sheep (Álvarez et al. 2009b).

\section{Materials and methods}

Blood samples were obtained from a total of 162 reproductive-age individuals belonging to the three Burkinabé sheep populations: (a) Burkina-Sahel (46), kept in the arid Sahel area covering the Northern part of Burkina Faso; (b) Djallonké (50), kept in the Sudan area, covering the Southern part of Burkina Faso; (c) Mossi (46), located in the Sudan-Sahel area, covering the central part of the country and one Niger sheep population: (d) Touareg (20). Further description of sampling and environmental conditions in which the Burkinabé sheep breeds are managed can be found in Traoré et al. (2008a) and Álvarez et al. (2009b).

Total DNA was isolated from blood samples using the Invisorb ${ }^{\circledR}$ Spin Micro DNA Kit (Invitek, Berlin, Germany) according to the manufacturer instructions. Diagnostic of $\operatorname{PrP}$ polymorphisms at codons $136(\mathrm{~A} / \mathrm{V}), 154(\mathrm{R} / \mathrm{H})$ and $171(\mathrm{R} / \mathrm{H} / \mathrm{Q} / \mathrm{K})$, were carried out on all individuals using a dual fluorescent multiprobe assay consisting of two closed tube PCR reactions containing four dual-labelled fluorescent ASO probes each, for the detection in real-time of the allelic variants of sheep PrP gene mentioned above. This protocol was run in an iCycler (Biorad, Barcelona, Spain), and is coincident with that described by Van Poucke et al. (2005) as modified by Traoré et al. (2008b) with the addition of a new fourth probe for the $171 \mathrm{~K}$ polymorphism in the second PCR reaction (see Table 1 at this reference and 171K: Cy5AGACCAGTGGATAAGTATAGTAACCA- BHQ2).
A fragment of $428 \mathrm{bp}$ of the PrP gene, including amino acids from 99 to 240, was amplified on five Burkinabe animals for which the standard genotyping assay failed using primers: for: 5'-GTGGAGGCTGGGGTCAAGGTGGTAG3 ' and rev: 5'-AAAGAGATGAGGAGGATCACAGGAC-3'. PCR conditions were as follows: the final reaction volume was $10 \mu \mathrm{l}$; the reaction mixture consisted on $50-100 \mathrm{ng}$ of genomic DNA, $0.2 \mathrm{U}$ of Taq polymerase (Biotools, Madrid, Spain), $0.25 \mu \mathrm{M}$ of each primer (Sigma-Aldrich, Madrid, Spain), $200 \mu \mathrm{M}$ of each dNTP (Biotools, Madrid, Spain) and $2 \mathrm{mM} \mathrm{MgCl2}$. The PCR protocol were run in an GeneAmp@ PCR System 9700 (Applied Biosystems, Madrid, Spain) and included an initial step of $95^{\circ} \mathrm{C}(3 \mathrm{~min})$, followed by 40 cycles of $30 \mathrm{~s}$ at $95^{\circ} \mathrm{C}$ for DNA denaturation, $30 \mathrm{~s}$ for primer annealing at $55^{\circ} \mathrm{C}$ and $30 \mathrm{~s}$ at $72^{\circ} \mathrm{C}$ for primer extension. PCR product was purified with the exoSAP-IT ${ }^{\circledR}$ protocol (USB, Barcelona, Spain) and sequenced in both strands by using the BigDye ${ }^{\circledR}$ Terminator v3.1 Cycle Sequencing Kit (Applied Biosystems, Madrid, Spain) following manufactured recommendations, on a ABI310 sequencer analyser (Applied Biosystems, Madrid, Spain). Sequences were appraised by eye and aligned by using Clustal in the MEGA 4.0 software (Tamura et al. 2007).

For informative purposes, individual genotypes were classified in five risk groups from R1 (very low) to R5 (greatest risk), according to the European Union regulations (Álvarez et al. 2007). A brief description of the characteristics of the risk groups is as follows: $\mathrm{R} 1$, very low risk both at the individual and at the progeny level; R2, low risk both at the individual and at the progeny level; R3, low risk at the individual level and not low at the progeny level depending on the genotype of the other parent; R4,scrapie occasionally recorded at the individual level and higher risk than in R3 progeny at the progeny level; and R5, greatest risk both at the individual and at the progeny level
Table 1 Genotypic and allelic frequencies for the PrP gene in four West African sheep populations. Frequencies are given in absolute values and as percentages (in brackets). Classification of PrP genotype in risk groups and sample size per population are also given

\begin{tabular}{|c|c|c|c|c|c|c|}
\hline & \multirow[b]{2}{*}{ Risk group } & \multicolumn{4}{|l|}{ Population } & \multirow[t]{2}{*}{ Total } \\
\hline & & Burkina-Sahel & Djallonké & Mossi & Touareg & \\
\hline Sample size & & 46 & 50 & 46 & 20 & 162 \\
\hline \multicolumn{7}{|l|}{ Allele } \\
\hline AHQ & & $6(6.5)$ & $8(8.0)$ & $9(9.8)$ & $13(32.5)$ & $36(11.1)$ \\
\hline ARQ & & $82(89.1)$ & $92(92.0)$ & $80(87.0)$ & $27(67.5)$ & $281(86.7)$ \\
\hline ARR & Highly resistant & $4(4.4)$ & - & $3(3.2)$ & - & $7(2.2)$ \\
\hline \multicolumn{7}{|l|}{ Genotype } \\
\hline AHQ/AHQ & $\mathrm{R} 2$ & - & $1(2.0)$ & $1(2.2)$ & $1(5.0)$ & $3(1.9)$ \\
\hline ARR/AHQ & & $1(2.2)$ & - & - & - & $1(0.6)$ \\
\hline ARQ/AHQ & $\mathrm{R} 3$ & $5(10.9)$ & $6(12.0)$ & 7 (15.2) & $11(55.0)$ & $29(17.9)$ \\
\hline ARR/ARQ & & $3(6.5)$ & - & $3(6.5)$ & - & $6(3.7)$ \\
\hline ARQ/ARQ & $\mathrm{R} 4$ & $37(80.4)$ & $43(86.0)$ & $35(76.1)$ & $8(40.0)$ & $123(75.9)$ \\
\hline
\end{tabular}


Genotypic $\left(f_{i j}\right)$ and allelic $\left(p_{i}\right)$ frequencies were calculated, respectively, as $f_{i j}=\frac{n_{i j}}{N}$ and $p_{i}=\frac{2 f_{i i}+\sum f_{i j}}{2}$, where $n_{i j}$ is the number of animals with the genotype $i j$ and $N$ is the number of total animals studied in each breed (Gama et al. 2006).

\section{Results}

Genotypic and allelic frequencies of the PrP gene for the sampled populations are given in Table 1. The ARQ allele was the most frequent in both the Burkinabé (86.7\%) breeds and Niger (67.5\%) breeds. The highly sensitive allele VRQ was not found in any of the sampled individuals. The highly resistant ARR allele was at very low frequency in the Burkina-Sahel and Mossi populations and was not present in the Djallonké and Touareg populations. Five out of 15 possible PrP genotypes were identified in the sampled individuals. The ARQ/ARQ genotype, which is classified at the undesirable risk level R4, was the most frequent in the all the African sample populations (75.9\%). No favourable ARR/ARR genotypes were found.

Five Burkinabé samples did not give consistent results at codons $136(\mathrm{~A} / \mathrm{V})$ and $171(\mathrm{R} / \mathrm{H} / \mathrm{Q} / \mathrm{K})$. These samples were sequenced to allow a correct diagnostic. No new polymorphism was found on codons 136, 154 or 171. However, seven mutations at codons 116, 138, 143, 151, 172, 176 and 240 , as well as two silent mutations at codons 231, 237 were found (Table 2).

\section{Discussion}

Among breeds, there is a large variation of allelic and genotypic frequencies on the PrP gene (Álvarez et al.

Table 2 Additional polymorphisms on PrP gene in three native Burkina Faso sheep populations

\begin{tabular}{|c|c|c|}
\hline Mutation & Population & Reference \\
\hline A116P & Djallonké & This work \\
\hline S138S & Mossi & This work \\
\hline H143R & $\begin{array}{l}\text { Burkina-Sahel, } \\
\text { Djallonké, } \\
\text { Mossi, }\end{array}$ & $\begin{array}{l}\text { DeSilva et al. 2003; Heaton et al. 2003; } \\
\text { Álvarez et al. } 2011\end{array}$ \\
\hline $\mathrm{R} 151 \mathrm{G}$ & Djallonké & Acín et al. 2004 \\
\hline Y172D & Djallonké & $\begin{array}{l}\text { Acín et al. 2004; Serrano et al. 2007; } \\
\text { Ün et al. 2008; Álvarez et al. } 2011\end{array}$ \\
\hline N176K & Mossi & Vaccari et al. 2001 \\
\hline $\mathrm{R} 231 \mathrm{R}$ & Djallonké & Ün et al. 2008 \\
\hline L237L & Djallonké, Mossi & This work \\
\hline S240P & Mossi & This work \\
\hline
\end{tabular}

2007, 2009a; Gootwine et al. 2008; Lühken et al. 2008; Passos et al. 2008). In this work, the ARR allele was only detected in the Burkina-Sahel and the Mossi populations. With support in both morphological and microsatellite information, it has been suggested that the Mossi breed can be considered as a transition population formed by a continuous gene flow from Sahelian sheep into the Djallonké (West African Dwarf) breed (Traoré et al. 2008a; Álvarez et al. 2009b).

The results obtained here for the four West African sheep are consistent with the recent reports by Kipanyula et al. $(2008,2009)$ in Tanzanian sheep. The alleles found in these West African population were basically the same as those (AHQ, ARH, ARQ and ARR) found in these two Sub-Saharan Africa populations, with the ARQ allele frequency varying from 0.772 to 0.905 in the two studied Tanzanian sheep breeds (Black Head Persian and Red Maasai, respectively). Also, the ARQ/ARQ genotype was the most frequent in the two Tanzanian breeds (63.3\% and $81.0 \%$, respectively) and there was no presence of the ARR/ARR genotype. The ARQ allele is thought to represent the ancestral form of the PrP gene. This allele is usually present at high frequencies in breeds traditionally raised under harsh conditions (Gama et al. 2006). The overall scenario showed here may be different for Mediterranean African sheep. Serrano et al. (2007) in Moroccan sheep breeds reported that the ARR allele frequency varied from $25.85 \%$ to $31.83 \%$; $31.83 \%$; with the frequency of the ARR/ARR genotype being relatively high (from $4.49 \%$ to $16.28 \%$ ).

The performance of RT-PCR diagnostic protocol used here has been shown to be affected when polymorphisms involve the flanking regions of the codons subject to diagnostic (Traoré et al. 2008b). The sequencing of several samples, has allowed us to demonstrate that West African sheep populations still showed some diversity on PrP gene (see Table 2), that may be profitable for future breeding programmes.

As in many developing countries worldwide, there is not a scrapie surveillance system in West Africa. Therefore, the incidence of the disease in the sampled populations, if existent, is not known. In such scenario, the implementation of a preventive selection programme aimed at increased resistance could conceivably be suggested. However, as suggested in other African sheep (Kipanyula et al. 2009), before embarking on such a scheme, it would be advisable to determine whether or not scrapie poses a problem. In any case, the results reported here should dissuade from this idea. The very low frequency of the ARR allele in West African sheep would limit the available genetic variability for breeding, resulting in extreme erosion of the genetic stock, if selection was solely for this allele. 
Acknowledgements This paper was partially funded by grants from the International Atomic Energy Agency, no. BKF/5/006, MICINN, no. CGL2008-03949/BOS and the Government of Principado de Asturias no. IB09-114. The research stay of Amadou Traoré, DVM, at SERIDA-Somió was supported by fellowship grant no. BKF/06023 from the International Atomic Energy Agency.

\section{References}

Acín, C., Martín-Burriel, I., Goldmann, W., Lyahyai, J., Monzón, M., Bolea, R., Smith, A., Rodellar, C., Badiola, J.J. and Zaragoza, P., 2004. Prion protein gene polymorphisms in healthy and scrapieaffected Spanish sheep. Journal of General Virology, 85, 21032110.

Alfonso, L., Parada, A., Legarra, A., Ugarte, E. and Arana, A., 2006. Effects on genetic variability of selection against scrapie sensitivity in the Latxa Black-Faced sheep. Genetics Selection Evolution, $38,495-511$.

Almeida, A.M., 2011. The Damara in the context of Southern Africa fat-tailed sheep breeds. Tropical Animal Health and Production, 43, 1427-1441.

Álvarez, I., Royo, L.J., Gutiérrez, J.P., Fernández, I., Arranz, J.J. and Goyache, F., 2007. Genetic diversity loss due to selection for scrapie resistance in the rare Spanish Xalda sheep breed. Livestock Science, 111, 204-212.

Álvarez, I., Gutiérrez, J.P., Royo, L.J., Fernández, I. and Goyache, F., 2009a. Quantifying diversity losses due to selection for scrapie resistance in three endangered Spanish sheep breeds using microsatellite information. Preventive Veterinary Medicine, 91, 172178.

Álvarez, I., Traoré, A., Tambourá, H.H., Kaboré, A., Royo, L.J., Fernández, I., Ouédraogo-Sanou, G., Sawadogo, L. and Goyache, F., 2009b. Microsatellite analysis characterizes Burkina Faso as a genetic contact zone between Sahelian and Djallonké sheep. Animal Biotechnology, 20, 47-57.

Álvarez, L., Gutiérrez-Gil, B., Uzun, M., Primitivo, F.S. and Arranz, J. J., 2011. Genetic variability in the prion protein gene in five indigenous Turkish sheep breeds. Small Ruminant Research, 99, 93-98

DeSilva, U., Guo, X., Kupfer, D.M., Fernando, S.C., Pillai, A.T., Najar, F.Z., So, S., Fitch, G.Q. and Roe, B.A., 2003. Allelic variants of ovine prion protein gene (PRNP) in Oklahoma sheep. Cytogenetics and Genome Research, 102, 89-94.

Ekateriniadou, L. ., Kanata, E., Panagiotidis, C., Nikolaou, A., Koutsoukou, E., Lymberopoulos, A.G. and Sklaviadis, T., 2007. PrP genotypes in scrapie-affected sheep in GreeceThe contribution of the AHQ 1 polymorphism. Small Ruminant Research, 73, 142-149.

Gama, L.T., Carolino, M.I., Santos-Silva, M.F., Pimenta, J.A. and Costa, M. S., 2006. Prion protein polymorphisms and breeding strategies in Portuguese breeds of sheep. Livestock Science, 99, $175-184$.

Gootwine, E., Abdulkhaliq, A., Jawasreh, K.I.Z. and Valle-Zárate, A., 2008. Screening for polymorphism at the prion protein (PrP) locus (PRNP) in Awassi and Assaf populations in Israel, the Palestinian Authority and Jordan. Small Ruminant Research, 77, 80-83.
Heaton, M.P., Leymaster, K.A., Freking, B.A., Hawk, D.A., Smith, T. P., Keele, J.W., Snelling, W.M., Fox, J.M., Chitko-McKown, C.G. and Laegreid, W.W., 2003. Prion gene sequence variation within diverse groups of U.S. sheep, beef cattle, and deer. Mammalian Genome, 14, 765-77.

Kipanyula, M.J., Chuma, I.S., Brundtland, E., Bårdsen, K. and Ulvund, M. J., 2008. Genotyping of the prion protein $(\mathrm{PrP})$ gene in Red Maasai and Black Head Persian sheep in Tanzania. Small Ruminant Research, 79, 146-151.

Kipanyula, M.J., Chuma, I.S., Brundtland, E., Bårdsen, K. and Ulvund, M.J., 2009. Prion protein (PrP) gene polymorphism in Red Maasai and Black Head Persian sheep breeds in Tanzania: Consistent profile regardless of locations. Small Ruminant Research, 86, 5255.

Lühken, G., Lipsky, S., Peter, C. and Erhardt, G., 2008. Prion protein polymorphisms in autochthonous European sheep breeds in respect to scrapie eradication in affected flocks. Small Ruminant Research, 75, 43-47.

Nsoso, S.J., Podisi, B., Otsogile, E., Mokhutshwane, B.S. and Ahmadu, B., 2004. Phenotypic Characterization of Indigenous Tswana Goats and Sheep Breeds in Botswana: Continuous Traits. Tropical Animal Health and Production, 36, 789-800.

Passos, D.T., Ribeiro, L.A.O., Rodrigues, N.C., Heppa, D. and Weimer, T.A., 2008. PrP polymorphisms in Brazilian sheep. Small Ruminant Research, 74, 130-133.

Serrano, C., Martín-Burriel, I., Lyahyai, J., Monzón, M., El Hamidi, M., Acín, C., Badiola, J., Tligui, N. and Zaragoza, P., 2007. Polymorphisms of the PRNP gene in Moroccan sheep breeds. Veterinary Record, 161, 524-525.

Tamura, K., Dudley, J., Nei, M. and Kumar, S., 2007. MEGA4: Molecular Evolutionary Genetics Analysis (MEGA) software version 4.0. Molecular Biology and Evolution, 24, 1596-1599.

Traoré, A., Tamboura, H.H., Kabore, A., Royo, L.J., Fernández, I., Álvarez, I., Sangare, M., Bouchel, D., Poivey, J.P., Francois, D., Toguyeni, A., Sawadogo, L. and Goyache, F., 2008a. Multivariate characterization of morphological traits in Burkina Faso sheep. Small Ruminant Research, 80, 62-67.

Traoré, A., Royo, L.J., Álvarez, I., Fernández, I., Gutiérrez, J.P., Rincón, C., Pérez-Pardal, L. and Goyache F., 2008b. Mutaciones adyacentes a los codones 136 y 171 del gene PrnP ovino afectan al protocolo diagnóstico basado en RT-PCR acoplados a sondas fluorescentes (in Spanish, with English abstract). ITEA, 104, 106-109.

Ün, C., Oztabak, K., Ozdemir, N., Ak1s, I. and Mengi, A., 2008. Genotyping of PrP gene in native Turkish sheep breeds. Small Ruminant Research, 74, 260-264.

Vaccari, G., Petraroli, R., Agrimi, U., Eleni, C., Perfetti, M.G., Di Bari, M.A., Morelli, L., Ligios, C., Busani, L., Nonno, R. and Di Guardo, G., 2001. PrP genotype in Sarda breed sheep and its relevance to scrapie. Brief report. Archives of Virology, 146, 2029-37.

Van Poucke, M., Vandesompele, J., Mattheeuws, M., Van Zeveren, A. and Peelman, L. J., 2005. A dual fluorescent multiprobe assay for prion protein genotyping in sheep. BMC Infectious Diseases, 5, 13. doi:10.1186/1471-2334-5-13

Windig, J.J., Meuleman, H. and Kaal, L., 2007. Selection for scrapie resistance and simultaneous restriction of inbreeding in the rare sheep breed 'Mergellander'. Preventive Veterinary Medicine, 78, 161-171. 